\title{
Deltagerorienteringen i undervisningen af MPA studerende - refleksioner og praksis
}

\author{
J.C. Ry Nielsen, ekstern lektor, Copenhagen Business School
}

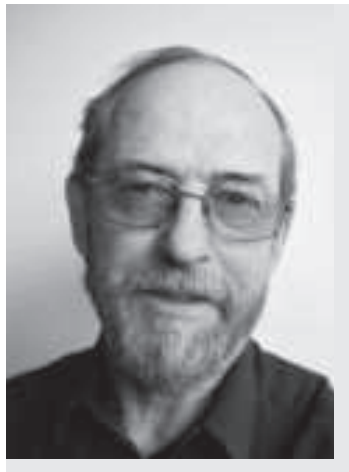

J. C. Ry Nielsen var i mange år lektor i organisationsteori på Copenhagen Business School (CBS). Han var med til at starte Master of Public Administration (MPA) uddannelsen i 1994, har været studieleder på uddannelsen fra starten og senere medlem af studieledelsen indtil I. marts 2007. Her overgik han til pensionisttilværelsen, men dog stadig med en tilknytning til MPA uddannelsen på deltidsbasis. Ud over MPA pædagogik har Ry Nielsens forskning været fokuseret på ledelse og organisationsændringer.

Praksisrelation er en vigtig bestanddel af padagogikken på Copenhagen Business School (CBS).

$P \AA$ MPA uddannelsen er vi privilegerede $i$ denne sammenhong, fordi vore deltagere med en gennemsnitsalder på over 40 år selv moder op med megen erfaring. Vores opgave som undervisere og designere af uddannelsen er at skabe rammerne for, at deltagernes erfaringer kan bringes $i$ spil ud fra mottoet "fra norhed til distance - og tilbage igen ". Forfatteren gengiver bade de mere overordnede overvejelser, man har gjort sig på uddannelsen, og en rakke af de mere praktiske tiltag, der har voret sat $i$ vork. ${ }^{1}$

\section{Introduktion - baggrunde og fremgangsmåde}

\section{Baggrund 1 - predagogik på CBS}

$\mathrm{På}$ CBS har der i mange år været en stor interesse for pædagogiske/didaktiske spørgsmål. På det organisatoriske plan viser dette sig ved, at der er oprettet en selvstændig enhed - CBS Learning Lab - som en intern konsulent- og udviklingsenhed. Enheden har i 1998 været med til at udforme pædagogiske principper for det erhvervsøkonomiske fakultet, og i 2005 har man udformet en læringsstrategi for CBS (www.cbs.dk). I papirerne hedder det bl.a.:

- at såvel undervisning som projekter tager udgangspunkt i praksisrelaterede problemer

- at der lægges vægt på dialog, caseundervisning og projekter og endelig

- at uddannelserne er praksisrelaterede og problemorienterede

Praksisrelateringen og variation i undervisningsformer er således centrale elementer i den forståelse af pædagogik, der er fremherskende på CBS. Det er så naturligvis op til de enkelte studier, hvordan man i praksis vil udforme og konkretisere disse idéer. I denne artikel vil jeg gerne demonstrere, hvordan vi på Master of Public Administration (MPA) uddannelsen har grebet nogle af disse problemstillinger an. Som det vil fremgå, får praksisrelateringen nogle helt andre udfoldelsesmuligheder, når det drejer sig om studerende med en stor egen praksisbaggrund. Her bliver undervisningen også et spørgsmål om at støtte de processer, der hele tiden foregår $i$ hovedet på deltagerne, når de relaterer undervisningens indhold til deres egen hverdag (Ry Nielsen, 2007b).

\section{Baggrund 2 - et MPA hold}

Et MPA hold har normalt 45 studerende. Med en gennemsnitsalder på over fyrre år repræsenterer holdet således knap 2000 års livserfaring, 800 års erhvervserfaring og 400 års ledererfaring. Holdet er således fyldt med levende cases. Alle har en erfaring, der kan bringes i spil.

Stort set alle har endvidere en mellemlang eller længerevarende højere uddannelse med i bagagen. 
Et MPA hold ligner således med hensyn til alder og erfaring slet ikke et normalt hold på en højere læreanstalt. Det tæetteste, man kommer, er et HD-hold.

Deltagerne, men normalt deres arbejdsgivere, betaler også relativt mange penge for uddannelsen, ca. $150.000 \mathrm{kr}$. Valget af uddannelsen er derfor et meget bevidst og gennemtænkt valg, som også kræver familiens opbakning.

Alt dette fører til høje forventninger om udbytte, men heldigvis også til høj grad af motivation.

Denne baggrund gør, at for de fleste af os undervisere er der stor fornøjelse forbundet med at undervise på et MPA hold. Men der er også pædagogiske udfordringer, som de krævende og engagerede studerende giver anledning til.

Her vil jeg kun tage fat $\mathrm{i}$ en enkelt, men meget central udfordring: Hvordan har vi prøvet over tid at fă nyttiggjort deltagernes erfaringer i undervisningssituationen og i opgaver?

Jeg skriver meget bevidst provet at, fordi vi må erkende, at handlinger med Poul Henningsens ord sjældent er fejlfrie, men intentioner er det ofte...

\section{MPA (Master of Public Administration)}

uddannelsen ved Handelshøjskolen i København er en toårig uddannelse på deltid. Uddannelsen er én af de ældste masteruddannelser i Danmark. Det første hold startede i 1994.

Målgruppen og dermed deltagerne er ledere primært fra offentlige og frivillige organisationer. Hertil kommer ledere fra fagforeninger og arbejdsgiverorganisationer og enkelte fra den private sektor.

Formålet med uddannelsen er at uddanne forandringsagenter.

Uddannelsen er meget enkel i sin opbygning, idet den består af:

tre kernefag - økonomi, politologi og organisationsteori

tre valgfag, som er uddybninger af kernefagene

faget Strategi og ændringer, som binder det hele sammen

Der sluttes af med en masterafhandling.

Uddannelsen har to internationale islæt:

- Det første år afholdes der en international sommerskole med deltagere fra en række europæiske lande. Det andet år tager de studerende på et selvvalgt udlandsophold, hvor de foretager sammenlignende analyser med henblik på deres masterafhandling.

Der optages ca. 45 studerende hvert år i januar. Yderligere oplysninger på www.mpa.dk

\section{Fremgangsmåde}

Jeg vil begynde artiklen med kort at skitsere, hvordan den oprindelige styregruppe for MPA uddannelsen greb den pædagogiske dimension i uddannelsen an. Dernæst vil jeg tage mere konkret fat $i$ de overvejelser, vi gjorde os om deltagerorienteringen og også senere om nogle af forudsætningerne for, at det skulle kunne lykkes. Efterfølgende vil jeg omtale og vurdere de mange initiativer, vi over tid har taget for at fremme deltagerorienteringen.

Min egen baggrund for skriveriet er en stor interesse i pædagogiske spørgsmål, men jeg er med Schöns ord en reflekterende praktiker og ikke professionel pædagog (Schön, 1983). Jeg er samtidig en af initiativtagerne til uddannelsen og er nu tilknyttet uddannelsen på deltidsbasis.

Det skal også nævnes, at MPA uddannelsen er beskrevet og analyseret i en række artikler og oplæg, senest i 2007 (Ry Nielsen, 2007a; 2007 b), som jeg også trækker på her. ${ }^{2}$

\section{Den pædagogiske dimension}

\section{Styregruppen og et vigtigt motto}

I den oprindelige styregruppe for MPA uddannelsen var vi alle meget indstillede på, at vi ikke kunne diskutere det faglige indhold uden samtidigt at diskutere den pædagogiske dimension. Styregruppen var herunder meget optaget af, hvordan vi kunne tilrettelægge en undervisning, der i så høj grad som muligt tog højde for, at deltagerne både har megen livserfaring og arbejdserfaring, jfr. ovenfor.

Til at illustrere dette fandt vi, syntes vi selv, et godt motto for uddannelsen: fra norhed til distance og tilbage igen. ${ }^{3}$ Alle vore deltagere møder som nævnt op med masser af erfaring. Vores opgave er at være fødselshjælpere i en proces, der skaber distance, således at deltagerne kan se på deres nære virkelighed med andre briller og få nye perspektiver. Dette gør vi ved at anvende masser af forskelligartet teori.Vi bruger således teori både på et højt og lavt abstraktionsniveau. Men det sker også i frugtbare erfaringsudvekslinger mellem deltagerne.

De fleste af vore deltagere bliver meget fascinerede af teorier. De oplever, at de får helt nye briller og perspektiver. På det helt lavpraktiske plan indebærer dette, at de for eksempel læser den daglige avis med andre briller. Men vores ambition er også, at deltagerne skal tilbage igen. Dette indebærer, at de også skal anvende deres nye viden til at forstå sig selv og deres egen organisation.

\section{Om roller og deltagerorientering}

En anden af styregruppens diskussioner drejede sig om rollerne i undervisningssituationen. Udgangspunktet var deltagernes baggrund i praksis, hvordan denne kunne udnyttes i undervisningssituationen, samt hvilke krav dette ville stille til underviserne. Resultatet af drøftelserne fremgår af følgende figur: 


\begin{tabular}{|l|l|}
\hline Deltagernes rolle & Undervisernes rolle \\
\hline Elev & Lærer \\
\hline Studerende & $\begin{array}{l}\text { Vejleder } \\
\text { Katalysator }\end{array}$ \\
\hline Ressourceperson & $\begin{array}{l}\text { Sparringspartner } \\
\text { Konsulent/mentor }\end{array}$ \\
\hline Rollevalg & Procesdesigner \\
\hline
\end{tabular}

Figur I. Deltagerroller og underviserroller.

Første række, 'elev/lærer', er den traditionelle rollefordeling. Læreren er den kloge, der skal hæve deltagerne op på et højere niveau, ofte ved envejskommunikation. Set med MPA-briller er den ikke ønskværdig i større omfang, men den er sikkert uundgåelig. Det er samtidig den rolle, de fleste undervisere føler sig mest trygge ved. Her definerer de nemlig selv indhold og form. Deltagerne sætter også pris på den - i hvert fald en gang imellem. Når de selv er trætte, og/eller når de får en fremragende forelæser.

Anden række, 'studerende/vejleder/katalysator', stiller større krav til begge parter. Deltagerne skal arbejde selvstændigt med stoffet, være nysgerrige og stille kritiske spørgsmål. Underviserne skal hjælpe deltagerne på vej, angive alternative indfaldsvinkler. Men da det normalt foregår inden for fagets rammer, er rollen måske ikke så svær.

Tredje række, 'ressourceperson/sparringspartner/ konsulent/mentor', stiller derimod betydeligt større krav til underviserne end til deltagerne. Disse skal 'blot' bruge deres erfaringer som udgangspunkt, mens underviserne skal mestre et bredt repertoire til at matche deltagernes problemstillinger. Dette vil normalt kræve erfarne undervisere og gerne med konsulenterfaring.

Som en positiv bivirkning kommer underviserne også i en lærende situation. Vi får gratis viden om en masse organisationer og deres problemer af enhver art. Deltagerne kommer også til at fungere i nye roller som sparringspartnere og konsulenter for deres medstuderende. ${ }^{4}$

Den fjerde række, 'rollevalg/procesdesigner', handler for deltagerne om, hvilken rolle de vil påtage sig, hvor aktive de vil være, og hvor meget og hvor åbent, de vil fortælle om deres organisation. Men det handler også om, hvor meget de vil udstille eventuel personlig usikkerhed.

For underviserne er det et spørgsmål om at vælge vægtningen af de forskellige indfaldsvinkler. Her forfalder vi som undervisere let til en ukritisk gentagelse af, hvad vi tror på som vægtning af forelæsninger, gruppearbejde og deltageroplæg. Og vi overser, at deltagerne måske først og fremmest ønsker sig variation, også fordi de kommer til undervisningen fra en normalt anstrengende arbejdsdag.

Diskussionen af de forskellige roller er fortsat gennem alle årene og altid med henblik på, hvordan vi i højere grad kan inddrage deltagerne som ressourcepersoner. De konkrete resultater af disse diskussioner vil fremgå af de følgende afsnit.

\section{Deltagerorienteringen i praksis}

\section{Introduktion - indhold}

I dette afsnit tager jeg fat på deltagerorienteringen fra fire forskellige indfaldsvinkler. Først noget om refleksion i dagligdagen, dernæst i form af et projekt, vi kalder deltagerprojektet. For det tredje noget om undervisning som workshop baseret på et eksempel fra egen undervisning og for det fjerde lidt om andre former.

\section{Dagligdagen}

Jeg vil begynde med at gentage, at en vigtig form for deltagelse er den daglige eftertanke, hvor vore studerende sætter undervisningen i relation til deres egen hverdag som borger, klient, patient, medarbejder og/ eller som leder. Den kan vi inspirere til og støtte op om, men det er jo de studerendes valg, hvor meget tid, de vil afsætte til en systematisk refleksion. Som en beskeden hjælp har vi i nogle år forsynet de studerende med følgende skema, men os bekendt har det ikke været anvendt særligt meget. Da vi imidlertid tror på idéen, kunne vi overveje at gøre som en enkelt af vore udenlandske kolleger ${ }^{5}$ gør det, nemlig at flette dagbogen eller dele af den ind i en eksamensopgave som en vigtig del af denne.

\begin{tabular}{|l|l|l|}
\hline dato & fag & $\begin{array}{l}\text { Personlige kommentarer om udbytte, kritik, undervisningens sværhedsgrad og kvalitet, } \\
\text { jeres egen aktivitet, følelser, gruppesamarbejdet, og hvad der ellers falder jer ind }\end{array}$ \\
\hline & økonomi & \\
\hline & politologi & \\
\hline & organisation & \\
\hline
\end{tabular}

Figur 2. Skema til refleksion 2006. 
Mere systemarisk har vi siden starten i 1994 haft to studerende til at reflektere over undervisningen i kernefagene, således at de tager fat på undervisningen sidste gang, man havde det pågældende kernefag. Fokus skulle være på vurdering/refleksion både af indhold og pædagogik,jf. også skemaet ovenfor. Det har imidlertid vist sig at være en svær øvelse for de studerende. De vil hellere referere end reflektere og vurdere. De har også svært ved at overholde en tidsgrænse på 10 minutter, og så synes det øvrige hold, at det tager for lang tid.

Som undervisere har vi haft det problem, at vi sommetider ikke var der sidste gang, eller vi finder fejl i oplæggene. Her har det været vores politik, at vi ikke blander os.

En kollektiv refleksion, hvor hele holdet inddrages, har vi ikke turdet binde an med. Holdet er for stort. I valgfagene, hvor holdene jo er langt mindre, er mulighederne bedre. I mit eget valgfag - Ledelsespraksis og ledelsesteori - har jeg prøvet med en kollektiv refleksion under titlen refleksion over - og siden sidst. Og det er tidskrævende. Med 12-15 studerende brugte vi ikke under en time på øvelsen.Vi var imidlertid enige om, at det var en meget frugtbar metode og en god tidsanvendelse, også fordi vi i høj grad kunne leve op til vores motto, som nu ikke var retorik, men praksis.

\section{Deltagerprojekt}

På vores første hold kom vi i forbindelse med den første skriftlige rapport ud for den overraskelse, at de studerende ikke vidste ret meget om samfundsvidenskabelig metode. Dette førte hurtigt til, at vi afsatte timer til metodeundervisning i forbindelse med de forskellige skriftlige rapporter på uddannelsen. Men det førte også til indførelsen af et gruppetræningsprojekt, som skulle have stor deltagerorientering, idet de studerende skulle vælge én eller flere af gruppemedlemmernes organisationer til analyse. Før selve projektet har vi formuleret følgende formål:

I. Komme bag om hverdagsproblemer - skabe distance

2. Opstille formål

3. Formulere et teoretisk problem og tilhørende spørgsmål - vælge iagttagelsespunkt

4. Overveje og vælge teori - data - metoder (vælge analysestrategi)

5. Foretage dataindsamling

6. Analysere ved hiælp af kernefag

7. Sammenhæng og konklusion - sprog

8. Refleksion over teori- og metodeanvendelse - gruppeprocesser - brug af vejleder

Figur 3. Formål for deltagerprojekt.

Vi er således ret ambitiøse på de studerendes vegne. De skal både arbejde problemorienteret, anvende nogle bestemte teorisæt, arbejde samfundsvidenskabeligt og sammen med nogle, der er anderledes samt komme fra nærhed til distance. Undervejs opponerer de også på en anden gruppes midtvejsrapport. Grupperne kaldes basisgrupper og består normalt af fire personer med vidt forskellig baggrund.

Oprindeligt var der ingen vejledning tilknyttet projektet, men efter en del år fandt vi ud af, at med vore store krav var det vigtigt, at vi brugte timer på vejledning. Som de fleste andre vil vi gerne bruge erfarne vejledere, men det lykkes ikke altid særligt godt. Der er for få, som vil bruge deres knappe ressourcer på den slags introducerende undervisning.

Tidsmæssigt begynder deltagerprojektet på introduktionsdagene i slutningen af januar hvert år og afsluttes op til sommerferien som afslutning på forårssemestret.

De forste mange år var behandlingen på introduktionsforløbet problemorienteret, dvs. de studerende havde hjemmefra formuleret et problem, de gerne ville diskutere med deres gruppe, og som måske skulle danne basis for det videre arbejde i deltagerprojektet. På det seneste har vi imidlertid fundet ud af, at dette nok var for ambitiøst. I stedet lægger vi nu vægt på, at der sker en vidensdeling i gruppen, således at alle fire medlemmer af basisgruppen får et godt kendskab til hinanden og hinandens organisationer. Dette gør de ved at interviewe hinanden i gruppen. Som støtte til interviewene har de fået en organisationsteoretisk artikel om Leavittmodellen (Ry Nielsen \& Ry, 2002). Disse interviews optager hele den første eftermiddag på intro. Forløbet definerer de studerende selv. Der er ingen undervisere til stede ved interviewene. Ifølge de studerende er processen både meget udbytterig og anstrengende. Det kræever, at man giver noget af sig selv og er koncentreret hele tiden.

Som yderligere et element $i$ vidensdelingen har vi i de seneste par år fået de studerende til lidt mere systematisk at fortælle om deres egen baggrund, jf. følgende figur. Det er også meningen, at vejleder for deltagerprojektet får det udfyldte skema.

Deltagerprojektet afvikles som nævnt gennem forårssemestret. Det støttes af metodeundervisning på holdet og vejledning til den enkelte gruppe. Litteraturmæssigt har vi skiftet meget ud, fordi vi har haft svært ved at finde relevant stof. Til støtte for analysen af egen organisation har vi altid brugt en artikel af Ry og Repstad, der analyserer dette. ${ }^{6}$

Deltagerprojektet er også det mest klare eksempel på, at vi systematisk bruger deltagerne som de ressourcepersoner, de er. Normalt er det kun én i hver gruppe, der får analyseret sin organisation. Som oftest med stort udbytte, men vi har også oplevet mange studerende, for hvem det var meget krævende - også følelsesmæssigt at skulle analysere deres egen organisation sammen med tre andre. Der kommer desuden let forhold frem, som gør, at de bliver nødt til at revidere deres syn på deres organisation. Dette gælder også deres eget virke i organisationen. 


\begin{tabular}{|l|l|l|l|}
\hline $\begin{array}{l}\text { NAVN på gruppemedlemmer } \\
\text { I-4 }\end{array}$ & $\begin{array}{l}\text { PROFESSIONEL } \\
\text { BAGGRUND }\end{array}$ & $\begin{array}{l}\text { LEDELSESERFARING } \\
\text { og/eller ANDEN } \\
\text { VIGTIG ERFARING }\end{array}$ \\
\hline I-4 & $\begin{array}{l}\text { NATurvidenskabelig } \\
\text { HUManistisk } \\
\text { SAMFundsvidenskabelig }\end{array}$ & $\begin{array}{l}\text { ØKonomi } \\
\text { ORGanisation } \\
\text { POLitologi }\end{array}$ \\
\hline $\begin{array}{l}\text { GRUPPENS ST/ERKE } \\
\text { OG SVAGE SIDER: }\end{array}$ & & \\
\hline
\end{tabular}

Figur 4. Skema til gruppeanalyse.

De deltagere, hvis organisation ikke bliver analyseret i deltagerprojektet, opfordrer vi til at analysere betydningen af den gennemførte analyse for dem selv og deres respektive organisationer. Dette gælder i øvrigt $i$ alle de skriftlige rapporter, man afleverer på uddannelsen, at der er et krav om en praksisrelateret refleksion.

\section{Workshopprag}

Både fra undervisningen på Handelshøjskolen og fra lederkurser havde vi gode erfaringer med aktivt at trække deltagernes erfaringer ind i undervisningen. Det kaldte vi workshops.

Oprindeligt var det vores håb i styregruppen, at meget af undervisningen skulle have et sådant workshoppræg. Det er imidlertid svært både for deltagere og undervisere systematisk at gennemføre undervisningen med et sådant præg, jf. afsnittet om roller ovenfor. Derfor er det også mere en vigtig dimension i undervisningen: hvordan kan vi få glæde af og udnytte de erfaringer, der findes på holdet.

Jeg vil imidlertid gerne give et eksempel på et undervisningsforløb, som havde et stærkt workshoppræg, og som både de studerende og jeg som underviser syntes, levede op til mottoet, fra noerhed til distance og tilbage igen.

Faget var et valgfag på 30 timer: Ledelsespraksis og ledelsesteori. Undervisningen afvikledes i 4 timers moduler med $i$ alt 7 undervisningsgange med omkring 15 deltagere. Normalt valgte jeg den litteratur, vi skulle anvende, og altid artikler, således at der var tre artikler pr. gang. På holdet aftalte vi, at det var tre studerende, der skulle gennemgå litteraturen hver gang. De skulle omtale artiklens indhold, hvad de selv kunne bruge den til, og hvilke spørgsmål, de syntes var værd at diskutere på holdet. Vi blev også enige om, at fire ud af de 7 gange skulle foregå i deltagernes organisationer.

Som tidligere nævnt begyndte undervisningen altid med en times kollektiv refleksion. Her kunne vi bl.a følge op på tidligere historier og dermed få en forløbsanalyse.

Når undervisningen foregik i en af deltagernes organisationer, var vedkommende deltager dernæst $\mathrm{i}$ fokus. Normalt ville en af de andre deltagere have fulgt ved- kommende en enkelt dag, og observationerne herfra blev fremlagt og diskuteret. Derefter ville deltageren i fokus fortælle lidt om organisationen, vi ville fă en rundvisning, og endelig ville vedkommende forelægge et ledelsesproblem til droftelse. Rundvisningen gav i øvrigt altid anledning til en vigtig diskussion af de fysiske rammer. Afslutningsvis kom de tre artikelgennemgange. De blev ofte lidt stedmoderligt behandlet. Derfor forøgede jeg tiden fra fire til fem timer.

Min egen rolle var at skabe en god og tryg stemning, at fastholde det analytiske perspektiv og komme med opsamlende, teoretiske oplæg.

De to hold, som jeg brugte denne fremgangsmåde sammen med, gav undervisningen en meget flot evaluering, og den var medvirkende til, at jeg fik to pædagogiske priser. ${ }^{7}$ Når det var så vellykket, hænger det naturligvis sammen med flere forhold. Det var et relativt lille hold med meget motiverede studerende. $\mathrm{Vi}$ kendte hinanden i forvejen, og det var kun i mit fag, det foregik på denne måde, og ikke samtidigt i mange fag. Temaet var naturligvis også befordrende, fordi det var så praksisorienteret.

Der ville i øvrigt ikke være noget $i$ vejen for, at man på ét eller to valgfagshold eksperimenterede med forskellige former for deltageraktivering.

\section{Andre former for deltageraktivering}

På uddannelsen er der en række opgaver/projekter, hvor de studerende kan vælge at inddrage deres egne erfaringer/organisationer. Det drejer sig om et 'kernefagsprojekt' som afslutning på det forste år, tre valgfag og et strategifag i år 2 samt endelig masterafhandlingen. Som andre studier har vi naturligvis et studienævn med studerende fra de to årgange repræsenteret.

Mere vigtig er imidlertid en af de studerende nedsat evalueringsgruppe. Allerede på introduktionsdagene vælger hver basisgruppe et medlem til evalueringsgruppen, som mødes med studieledelsen to gange $\mathrm{i}$ semestret. Her kan alt muligt tages op, og det har over tid vist sig at være et meget kritisk organ, men altid konstruktivt kritisk. Derfor er en del problemer eller utilfredsheder blevet taget i opløbet. Tonen er rå, men hjertelig. Det hjælper naturligvis, at vore studerende gennemgående er meget tilfredse med uddannelsen 
(Danmarks Evalueringsinstitut, 2002; Ry Nielsen, 2003)

På intro vælger de studerende ligeledes et dannelsesudvalg, som står for 3-4 dannelsesaftener i løbet af uddannelsen. Dannelse kan være at komme bag scenen på Det kongelige Teater eller møde Danmarks Radios generaldirektør. De studerende nedsætter også et festudvalg.

Der er således en bred vifte af aktiviteter, hvor de studerende er med til at præge hverdag og fest på holdet.

\section{Opsamling og afrunding}

I denne artikel har jeg villet demonstrere, hvordan MPA uddannelsen lever op til CBS' forestillinger om praksisorientering.

På uddannelsen er vi på dette område meget privilegerede, ved at vore studerende har en righoldig praksisbaggrund. I artiklen har jeg givet en række eksempler på, hvordan vi på uddannelsen både teoretisk og i praksis forvalter dette privilegium.

Noget af deltagerpraksisorienteringen er meget planlagt og systematisk og omfattende alle. Dette gælder aktiviteterne på introduktionsdagene.Vi lægger her megen vægt på det tryghedsskabende og vidensdelingen mellem basisgruppens medlemmer. Hertil kommer siden hen deltagerprojektet og den daglige evaluering af undervisningen. Andet er mindre systematisk eller omfatter ikke alle. Dette gælder fx workshoppræg i undervisningen og inddragelse af egen praksis i diverse opgaver og projekter.

Som det vil være fremgået, har ikke alle vore initiativer været lige succesfulde, men vi vil gerne hele tiden leve op til vores motto, Fra narhed til distance og tilbage igen, som en mere grundlæggende præmis i uddannelsen. Den hører naturligt til og burde 'sidde $i$ væggen'. Men vi ved godt, at det kræver tid, energi og kreative løsninger at komme så langt.

Vi er stadigvæk på vej.

\section{Referencer}

Danmarks Evalueringsinstitut (2002). Masteruddannelser: Evaluering af Master of Public Administration, Master of Public Management og Master of Public Policy. København

Ry Nielsen, J. C. (1988). Tanker om ledelse. København: Nyt fra Samfundsvidenskaberne. 2. rev. udgave

Ry Nielsen, J. C. (2003). MPA uddannelsen $i$ går $-i$ dag - $i$ morgen. En statusrapport. København: MPA uddannelsen, www.mpa.dk

Ry Nielsen, J. C. (2007a). MPA uddannelsen fra idé til succes, Festskrift $i$ anledning af MPA Norges 10 àrs jubilaum. Trondhjem. Også på www.mpa.dk

Ry Nielsen, J. C. (2007b). Taking seriously the experiences of our participants and facilitate what already goes on in their heads. Oplæg på International Pedagogical Workshop, CBS 14.-16. november 2007

Ry Nielsen, J. C. \& Repstad, P. (1993, 2004) Fra nærhet til distanse - og tilbake igjen - om å analysere sin egen organisasjon. I: P. Repstad (red.) Dugnadsaind og forsvarsverker. Oslo: Tanum. Optrykt i J.C. Ry Nielsen (1993) Anderledes tanker om livet $i$ organisationer København: Nyt fra Samfundsvidenskaberne, s.19-41

Ry Nielsen, J. C. \& Repstad, P. (1993a). From Nearness to Distance - and Back again. Copenhagen Business School: Papers in Organization no 14

Ry Nielsen, J. C. \& Repstad, P. (2006). Når mauren (myren) også skal være ørn. I: F. Nyeng \& G. Wennes (red): Tall, tolkning og tvil. Oslo: Cappelen Akademiske Forlag, pp. 244-278

Ry Nielsen, J. C. \& Ry, M. (2002). Anderledes tanker om Leavitt - en klassiker i ny belysning. København: Nyt fra Samfundsvidenskaberne

Ry Nielsen, J. C. \& Ry, M. (2004). Tanker om organisationsandringer - brikker til mange ukendte puslespil. København: Nyt fra Samfundsvidenskaberne

Schön, D. (1983). The Reflective Practitioner, New York: Basic Books

\section{Noter}

1 Jeg vil gerne takke redaktørerne for konstruktiv kritik af tidligere udgaver af artiklen. Deltagerne på en pædagogisk workshop på CBS i november 2007 kom også med gode bidrag.

2 På www.mpa.cbs.dk kan man se en oversigt over de mange publikationer, der findes om MPA uddannelsen

3 Mottoet var hentet fra en artikel, jeg havde skrevet sammen med Pål Repstad, en norsk kollega (Ry Nielsen \& Repstad, 1993, 2004, 2006)

4 Begge dele fremhævet afYusuf Ahmad fra University of the West of England i Bristol på workshop på CBS i november 2007

5 Annie Rubienska fra University of Birmingham

6 Se note 3 .

7 Efter dimissionen i januar 2006 besluttede 'ledelsespraksisholdet' sig for at fortsætte med at mødes hos hinanden. Jeg blev også indbudt, og vi mødes stadigvæk. 